This item was submitted to Loughborough's Research Repository by the author.

Items in Figshare are protected by copyright, with all rights reserved, unless otherwise indicated.

\title{
Electrical mismatch within single junction amorphous silicon and micromorph tandem thin film PV modules
}

PLEASE CITE THE PUBLISHED VERSION

http://dx.doi.org/10.1109/PVSC.2009.5411142

PUBLISHER

(C) IEEE

VERSION

VoR (Version of Record)

LICENCE

CC BY-NC-ND 4.0

\section{REPOSITORY RECORD}

Qiu, Yingning, Thomas R. Betts, and Ralph Gottschalg. 2019. "Electrical Mismatch Within Single Junction Amorphous Silicon and Micromorph Tandem Thin Film PV Modules". figshare.

https://hdl.handle.net/2134/8199. 
This item was submitted to Loughborough's Institutional Repository (https://dspace.lboro.ac.uk/) by the author and is made available under the following Creative Commons Licence conditions.

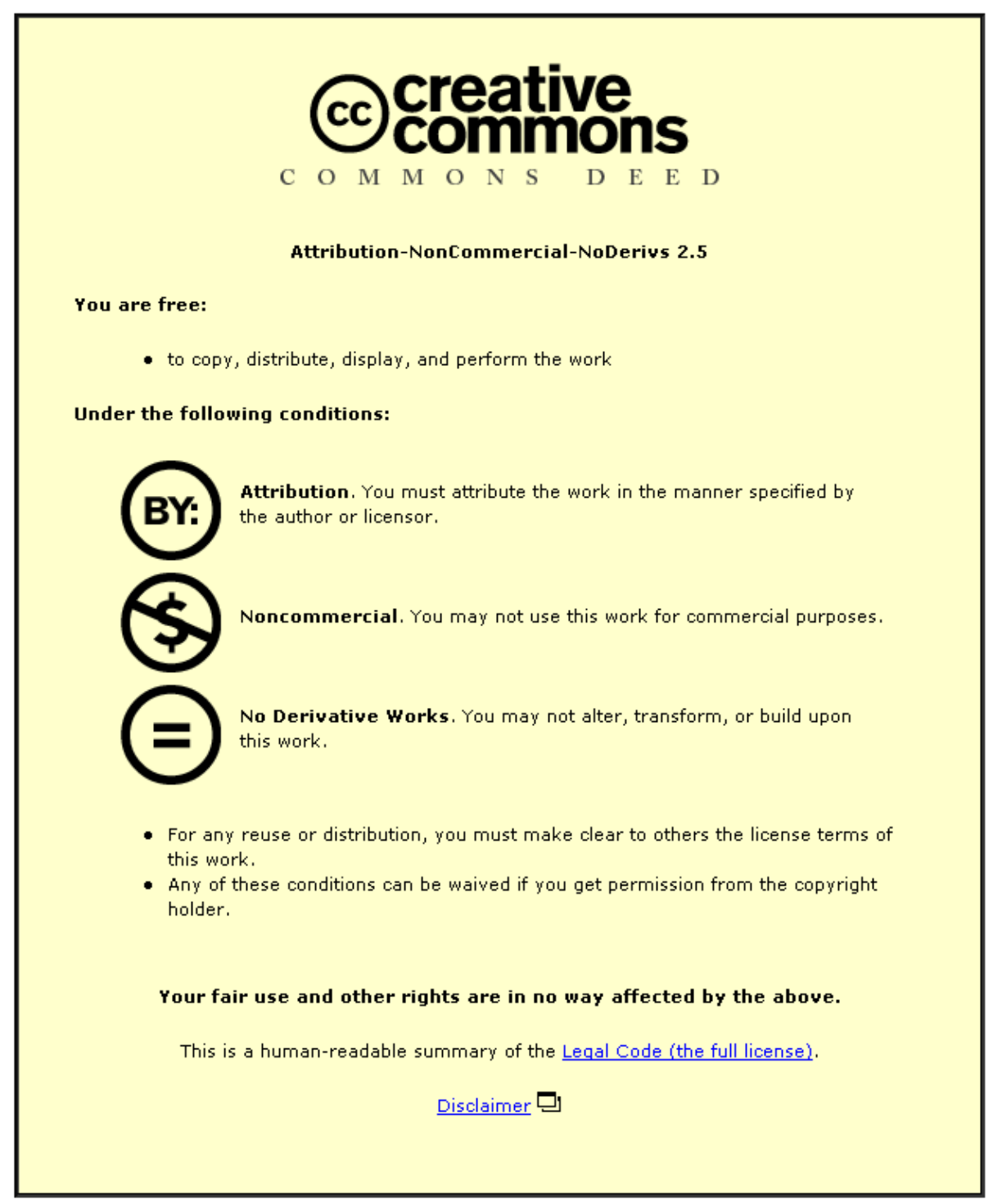

For the full text of this licence, please go to: http://creativecommons.org/licenses/by-nc-nd/2.5/ 


\title{
ELECTRICAL MISMATCH WITHIN SINGLE JUNCTION AMORPHOUS SILICON AND MICROMORPH TANDEM THIN FILM PV MODULES
}

\author{
Y.N. Qiu, T.R. Betts, R. Gottschalg \\ Centre for Renewable Energy Systems Technology (CREST), Department of Electronic and Electrical Engineering, \\ Loughborough University, Loughborough, Leicestershire, LE11 3TU, United Kingdom \\ Tel.: 01509-635336, Fax: 01509-635301, email: Y.Qiu@Iboro.ac.uk
}

\begin{abstract}
Due to the electrical mismatch between the individual cells, the actual efficiency of a PV module is always lower than the sum of the cells under normal measurement conditions. The effect of this electrical mismatch is simulated for single junction amorphous silicon PV modules as well as micromorph thin film PV modules. This paper reports on the design of the realistic parameter distribution for the I-V simulation. It shows that due to the current mismatch in a double junction solar cell, these devices seem to be more significantly affected by similar variation in parameters, which would indicate that tighter production control is necessary but also that it will be more involved to measure these devices with sufficient accuracy. It is shown that device mismatch actually results in a lower fill factor, which is slightly different to what is seen for single cells.
\end{abstract}

\section{INTRODUCTION}

Enhancing the efficiency of a solar cell and then that of a PV module is the target of intense research and development. In recent years, micormorph modules have entered the market place but they pose a significant complication in determining their accurate power rating. While in principle 'all' one would need to do is to use a perfect AM1.5 solar spectrum and regulate the device's temperature to the required $25^{\circ} \mathrm{C}$, in reality this is not as simple, as this spectrum does not exist. To remedy this, a reference cell is used, which is at best a representative sample of the test device under in a electrical condition which is not necessarily of the test sample. This poses problems in the calibration of micromorph samples. A number of round robin intercomparisons has been carried out with uncertainties between institutions easily reaching $15 \%$. This work develops some of the tools to understand this in order to explain differences in the reported deviations in round robin intercomparisons of micromorph modules on solar simulators calibrated to amorphous silicon modules. This requires setting up a realistic representation of the cell distribution in I-V as well as quantum efficiency and linking this to solar simulator spectra. This can then be used for a statistical Monte Carlo simulation of the measurement uncertainty. The first step is to understand the variability of produced samples - and as this tends to be highly confidential data an approximation needs to be developed that will represent realistic performance parameter distributions. A model for this is demonstrated here. This model will also allow the simulation of the effects of different solar simulators using a Monte-Carlo approach, which will be presented at a later stage.

The variation of electrical parameters of a single cell will even affect the design of large-scale PV generator [4]. In this study, the main concern is on the variations of the electrical parameters and how this influences the measured power. This requires to build distributions representing the electrical performance that might be measured at the end of a production line. These distributions are then used for the simulation of the calibration uncertainties seen due to lacking reference cells and variations within the spectrum in the solar simulation. The current mismatch of different cells occurring in double junction cells will affect the short circuit current of the cell and then will further influence the PV performance by increasing the fill factor (FF). In order to take all these issues into account, a modified equivalent circuit is used to simulate the I-V curve of a single junction a-Si solar cell and a micromorph tandem solar cell. All the input electrical parameters are defined by a probability density function (pdf), which is controlled by a mean value and a value of its standard deviation. With a statistical Monte Carlo simulation, the generated parameters are put into the circuit model and considering the current mismatch in a double junction solar cell the I-V curve is generated for a micromorph solar cell. In this paper, a module with 26 cells in series connection is simulated and the efficiency distribution is obtained and discussed.

The final factory test in solar cell production is a measurement of the electrical properties of any module produced, which then gives the rated power. There are no stable reference cells available for thin film silicon devices and one thus relies on the stability of the production batch to achieve reliable results. Especially for multi-junction devices, this repeatability might affect the overall measurement uncertainty disproportionally. This paper presents a methodology to simulate the required input for such a Monte-Carlo simulation.

\section{SIMULATION MODEL}


An improved equivalent circuit is used to simulate the I-V curve of micromorph tandem solar cell. It is illustrated as figure below:

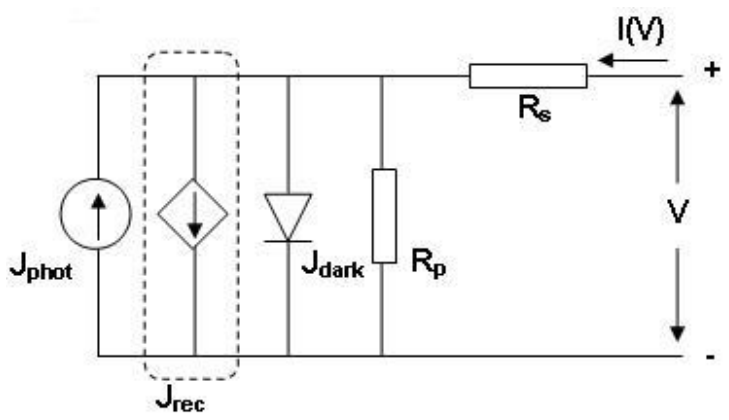

Fig 1. Equivalent circuit for a-Si:H and $\mu \mathrm{c}-\mathrm{Si}: \mathrm{H}$

The advantages of this model includes providing the information of sample degradation, having dependant on ilayer thickness and carrier lifetime related [5, 6]. The validation of this model to a-Si:H and $\mu \mathrm{c}-\mathrm{Si}: \mathrm{H}$ are discussed in ref 5 and 6 respectively. In addition, with the an ohmic term (current through the shunt resistance) and a non-linear multiplication factor describing reverse avalanche breakdown, the equivalent circuit can simulate the entire range of physically possible I-V conditions. The equivalent circuit include the avalanche breakdown is given below [7].

$$
\begin{aligned}
& J(V)=-J_{\text {phot }}+J_{\text {phot }} \cdot \frac{d i^{2}}{(\mu \tau)_{e f f}\left(V_{b i}-V+J R_{s}\right)}+ \\
& J_{s a t}\left[\exp \left\{\frac{q\left(V-J R_{s}\right)}{n k T}\right\}-1\right]+\frac{V-J R_{s}}{R_{p}}\left\{1+a\left(1-\frac{V-I R_{s}}{V_{b r}}\right)^{-m}\right\}
\end{aligned}
$$

Where $\mathrm{J}$ is the output current density $\left(\mathrm{A} \mathrm{cm}^{-2}\right)$, Jphot is the photocurrent density $\left(\mathrm{A} \mathrm{cm}^{-2}\right), \mathrm{J}_{\text {sat }}$ is the reverse saturation current density of the diode $\left(A \mathrm{~cm}^{-2}\right), R_{\mathrm{s}}$ is the series resistance $\left(\Omega \mathrm{cm}^{2}\right)$ and $n$ is the diode ideality factor. $V_{b i}$ is the build in voltage in silicon solar cell, $R_{p}$ is the cell shunt resistance $\left(\Omega \mathrm{cm}^{2}\right)$. J Jec depends on i-layer quality (recombination within $\mathrm{i}$ layers). di is the $\mathrm{i}$ layer thickness $(\mu \mathrm{m}),(\mu \mathrm{t})_{\text {eff }}$ is effective driftlength $\left(\mathrm{cm}^{2} / \mathrm{V}\right)$ where $\mu$ is free carrier mobility and $t$ is the capture times of carriers. $\left(\mathrm{cm}^{2} / \mathrm{V}\right) . \mathrm{Vbr}$ is the junction breakdown voltage $(\mathrm{V})$, $a$ is the fraction of ohmic current involved in avalanche breakdown and $\mathrm{m}$ is the avalanche breakdown exponent. For the simulations, a centre value needs to be chosen, those are detailed in Table I.

All the circuit parameters above are then used in a Monte-Carlo simulation buy simulating variations. These were calculated by a mean and standard deviation values.

$$
x=\sigma \cdot r+\bar{x}
$$

$\bar{x}$ is the mean value and $\sigma$ is the standard deviation (SD in table 1). $r$ is the random number generated with normally distribution. The constant value is $q-$ electron voltage, $\mathrm{k}$ - Boltzman constant $(\mathrm{J} / \mathrm{K})$ and $\mathrm{T}$ - cell's temperature $(\mathrm{K})$.

Table I - Electrical parameters for the equivalent circuit.

\begin{tabular}{|l|l|l|l|l|}
\hline $\begin{array}{l}\text { Parameter } \\
\text { s }\end{array}$ & \multicolumn{2}{l|}{$\begin{array}{l}\text { a-Si:H (for single } \\
\text { junction as well) }\end{array}$} & $\mu \mathrm{c}-\mathrm{Si}: \mathrm{H}$ \\
\hline & Mean & $\begin{array}{l}\text { Range } \\
(\mathrm{SD})\end{array}$ & Mean & $\begin{array}{l}\text { Range } \\
(\mathrm{SD})\end{array}$ \\
\hline $\begin{array}{l}\mathrm{I}_{0} \\
\left(\mathrm{~mA} / \mathrm{cm}^{2}\right)\end{array}$ & $5.0 \times 10^{-10}$ & & $13.0 \times 10^{-6}$ & \\
\hline $\mathrm{N}$ & 2 & $1 \%-5 \%$ & 1.26 & $1 \%-5 \%$ \\
\hline $\begin{array}{l}\mathrm{Rp} \\
\left(\Omega \mathrm{cm}^{2}\right)\end{array}$ & 2500 & $1 \%-5 \%$ & 2000 & $1 \%-5 \%$ \\
\hline $\begin{array}{l}\mathrm{Rs} \\
\left(\Omega \mathrm{cm}^{2}\right)\end{array}$ & 1.0 & $1 \%-5 \%$ & 0.0005 & $1 \%-5 \%$ \\
\hline $\mathrm{Vbi}(\mathrm{V})$ & 1.1 & $1 \%-5 \%$ & 1.1 & $1 \%-5 \%$ \\
\hline $\mathrm{di}(\mu \mathrm{m})$ & 0.35 & $1 \%-5 \%$ & 1.5 & $1 \%-5 \%$ \\
\hline$\mu \mathrm{t} \mathrm{cm} / \mathrm{V}$ & $7.7 * 10^{-8}$ & & $3.0 * 10^{-7}$ & \\
\hline $\mathrm{V}_{\text {break }}$ & -8 & & -8 & \\
\hline $\mathrm{a}$ & 0.1 & & 0.1 & \\
\hline $\mathrm{m}$ & 3.7 & & 3.7 & \\
\hline
\end{tabular}

The calculation of the total I-V curve for PV module is shown in figure 2 . The calculation details are described in the following section.

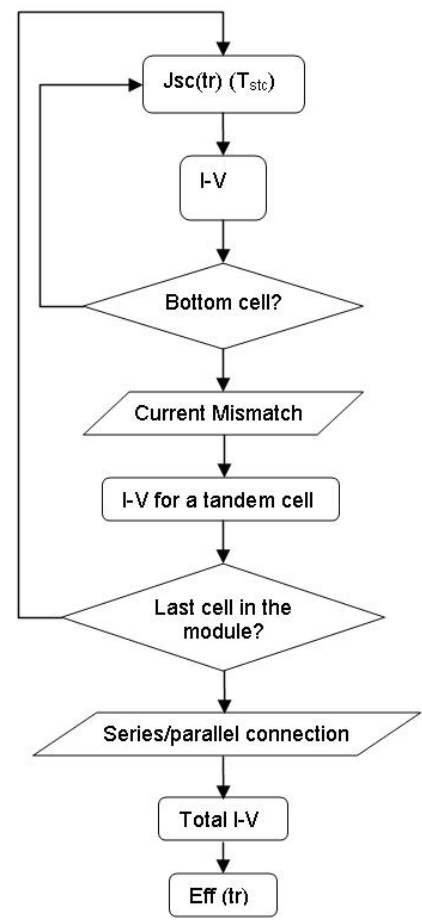

Fig. 2. Simulation of PV module efficiency for single junction and micromorph solar cell

The short circuit current of the tandem solar cell is determined by the integration between quantum efficiency and the spectral irradiance. Then with the parameter of 
equivalent circuit the I-V curve of a single junction is obtained until the last junction. If it is a multi-junction solar cell, the current mismatch should be considered here and the total I-V for a single cell is obtained. This calculation is repeated until the last cell in the module and with the series/parallel connection, the total $\mathrm{I}-\mathrm{V}$ for a module is obtained. Due to the double junction structure, the irradiance will be absorbed by the top junction and the rest light unabsorbed will penetrate to the bottom junction which is calculated as below:

$$
\begin{gathered}
I_{s c 1}=\int_{\lambda_{1}}^{\lambda_{2}} S R_{1}(\lambda) G(\lambda) d \lambda \\
I_{s c 2}=\int_{\lambda_{3}}^{\lambda_{4}} S R_{2}(\lambda) G(\lambda) d \lambda
\end{gathered}
$$

Where $G(\lambda)$ is the input spectral irradiance, SR1 is the spectral response of the top junction, $\mathrm{SR}_{2}$ is the spectral response of the bottom junction.

The simulation here is based on the standard test condiction, which are $\mathrm{AM} 1.5, \mathrm{~T}=25^{\circ} \mathrm{C}$ and the intensity is normalized to $1000 \mathrm{w} / \mathrm{m}^{2}$.

\section{RESULTS \& DISCUSSIONS}

With the mean value of the electrical parameter list in table I, the calculated I-V curve for the single junction a-Si and micromorph tandem solar cell are presented. For micromorph tandem solar cell, the I-V curve for top junction which is a-Si:H, bottom junction that is $\mu \mathrm{c}-\mathrm{Si}: \mathrm{H}$ and for the total randem cell are shown below and their performance data are shown in Table II:

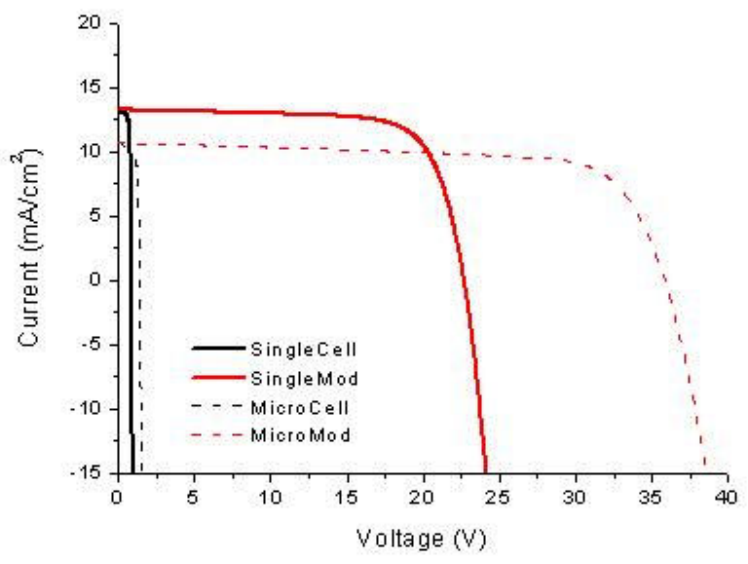

Fig. 3. simulated I-V curve for single junction a-Si, micromorph (a-Si:H/ $\mu \mathrm{c}-\mathrm{Si}: \mathrm{H} /)$ tandem solar cell and module.

Table II - Performance data of a-Si:H single junction and micromorph cell and module.

\begin{tabular}{|l|l|l|}
\hline Parameters & $\begin{array}{l}\text { a-Si:H } \\
\text { Single Juncion }\end{array}$ & $\begin{array}{l}\text { Micromorph } \\
(\mathrm{a}-\mathrm{Si}: \mathrm{H} / \mu \mathrm{c}-\mathrm{Si}: \mathrm{H})\end{array}$ \\
\hline
\end{tabular}

\begin{tabular}{|l|l|l|l|l|}
\hline & Cell & Module & Cell & Module \\
\hline $\begin{array}{l}\mathrm{J}_{\text {sc }} \\
\left(\mathrm{mA} / \mathrm{cm}^{2}\right)\end{array}$ & 13.20 & 13.20 & 10.66 & 10.66 \\
\hline $\mathrm{V}_{\text {oc }}(\mathrm{V})$ & 0.87 & 22.7 & 1.38 & 35.84 \\
\hline $\mathrm{FF}$ & 73.34 & 73.31 & 71.87 & 71.86 \\
\hline$\eta(\%)$ & 8.06 & 8.47 & 10.56 & 10.56 \\
\hline
\end{tabular}

With the SD varying from $1 \%$ to $5 \%$ input to the electrical parameters, it will produce different standard deviation of final efficiency output for a single cell. The effect of the electrical parameters to the performance of a cell is shown in figure 4 below:

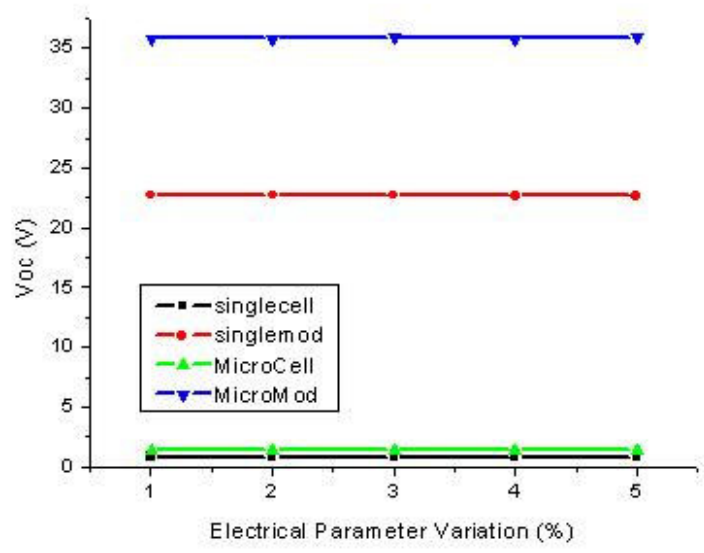

(a)

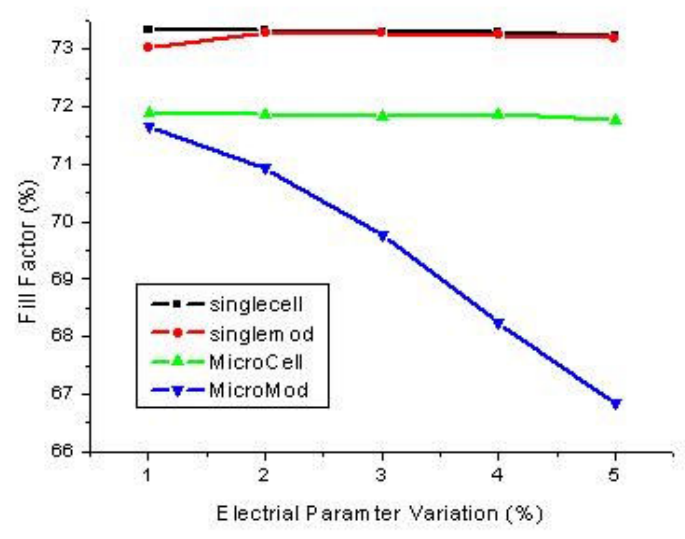

(b) 


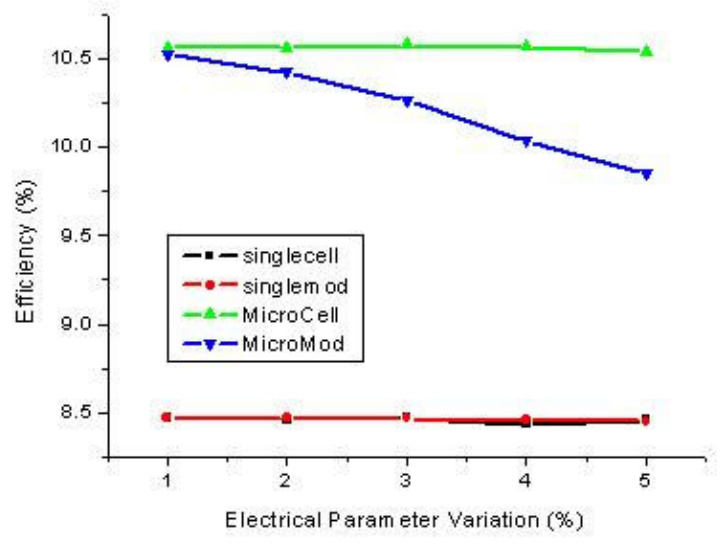

(c)

Fig. 4. Mean value of $\operatorname{Voc}(a), \operatorname{FF}(b)$ and efficiency (c) of single junction and micrimorph solar cell dependence on electrical parameters.

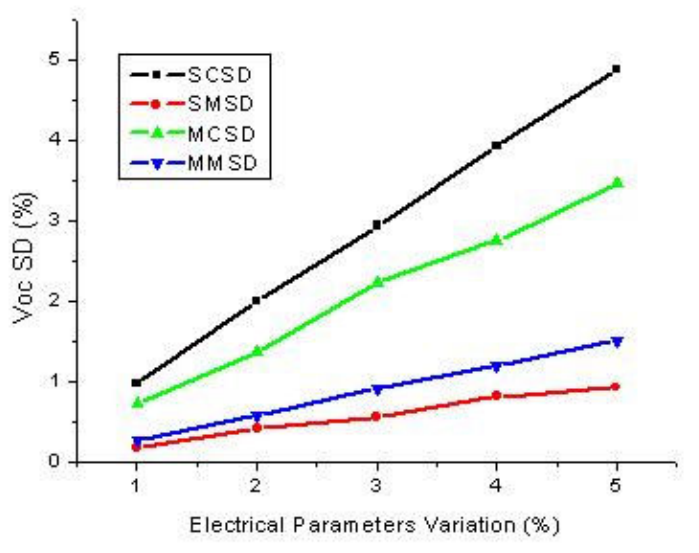

(a)

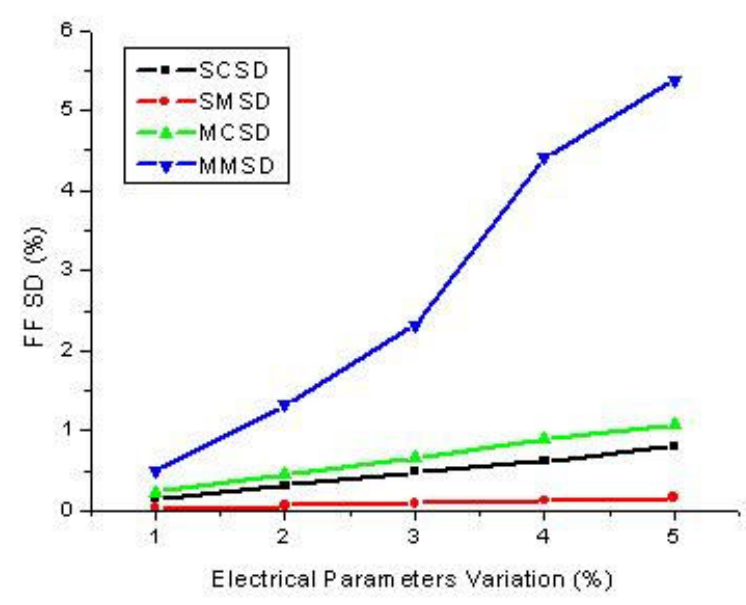

(b)

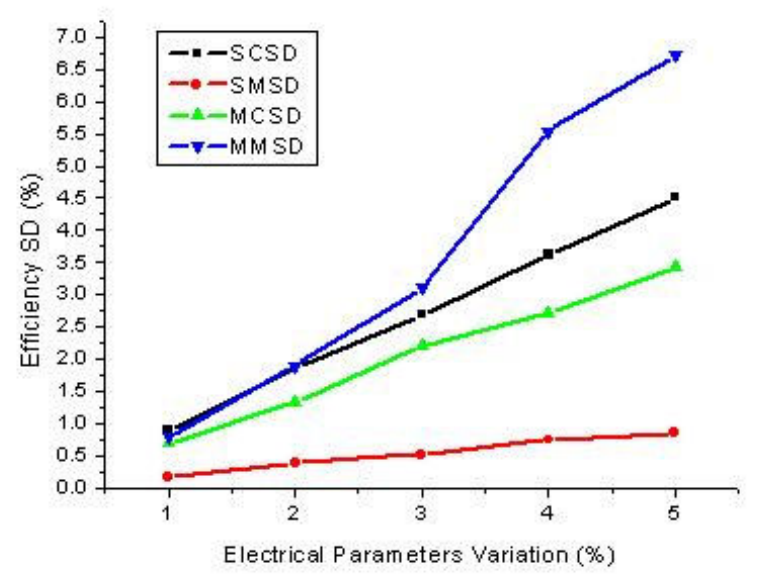

(c)

Fig. 5. Standard deviation of $\operatorname{Voc}(a), F F(b)$ and efficiency (c) of single junction and micrimorph solar cell and module dependence on electrical parameters.

As the variation of quantum efficiency here are neglected, therefore the variation in $\mathrm{J}_{\mathrm{sc}}$ is very small which is not shown here. Figure 4 shows that the mean value of open circuit voltage have little variation. However, the fill factor change significantly which further affects the efficiency value. The mean value of the efficiency of micromorph module reduces compared to the average single cell used as a starting point, i.e. it cannot utilise any gains being made for some cells. By figure 5 , it is observed that the short circuit current of a module has large standard deviation which is due to the current mismatch, which is not been observed in a single cell/module. The large standard deviation of single cell open circuit voltage is due to its relatively low value which further determines its efficiency standard deviation. 


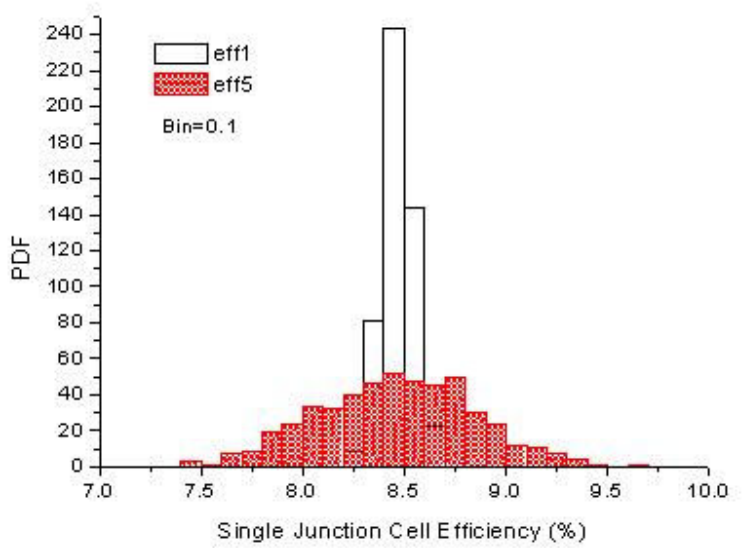

(a)

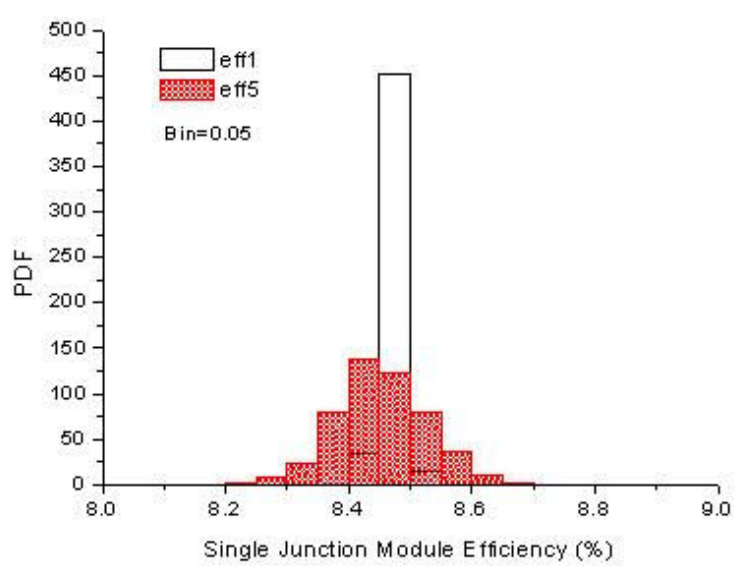

(b)

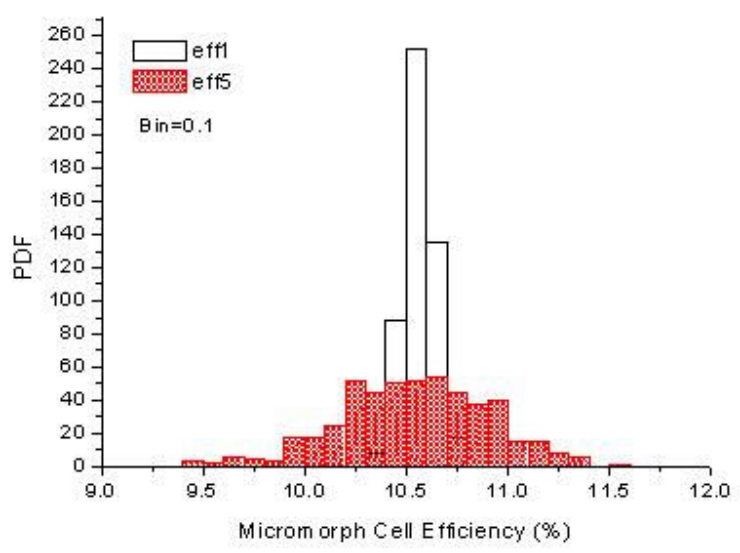

(c)

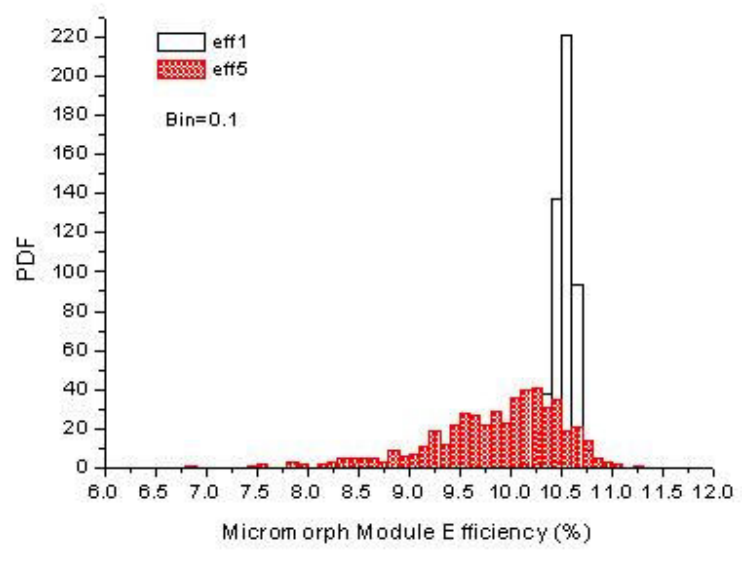

(d)

Fig. 6. Efficiency distribution for single junction cell (a), single junction module (b) and micromorph cell (c), micromorph module $(d)$.

Figure 6 shows that due to the current mismatch, a micromorph module shift the efficiency distribution to lower values which results in lower mean efficiency value. This has not been observed in a single junction module. This is illustrated in figure 5 (b), although a large standard deviation of a single junction solar cell efficiency is observed the distribution of the efficiencies are normally distributed (symmetrically), therefore, it does not reduce the mean value of a single junction cell's efficiency. Intrinsically, it is different from the micromorph cell and module. This is elaborated in figure 6 , where it shows that efficiency of micromorph PV module exhibit a long tail in the low efficiency range. That means connecting the solar cell with various electrical parameters, the module is limited by the cell with worst performance. However, due to the current mismatch of micromorph tandem solar cell, additional uncertainty is introduced due to the competition between the top junction and the bottom junction. Therefore, it will generate a wider efficiency distribution (pdf) for a PV module which causes a sharply increase of efficiency standard deviation and a sharp decrease of efficiency mean value with an increase of electrical parameters varieties. The increase speed of module efficiency SD vs parameters SD is in $1.68 /(\%)$ while the cell efficiency SD vs paramters SD is in $0.905 /(\%)$. With parameters SD above $5 \%$, the mean value of module efficiency will decrease sharply with 0.5 while no significant difference is observed for a single tandem solar cell.

\section{CONCLUSION}

The dependence of PV module efficiency distribution (pdf) to electrical parameters distribution (pdf) is investigated. It is found that for a micromorph tandem solar cell with electrical parameters SD up to $5 \%$, the performance of a PV module will be affected significantly. 
The reason for this is due to the current mismatch which has not been observed in a single junction cell and module. However, different connection strategy may need to be compared. In addition, a further investigation of effects from spectral mismatch error to the performance of PV modules should be performed.

\section{REFERENCES}

[1] Arai, Y. Ishii, M. Shinohara, H. Yamazaki, S. "A single p-i-n junction amorphous-silicon solar cell with conversion efficiency of $12.65 \% "$, IEEE Elect. Dev. Lett. 12, 1991, pp. 460-461

[2] D. Fischer et al., "The 'Micromorph' solar cell : extending a-Si:H technology towards thin film crystalline silicon", Proc. of 25th IEEE PVSC, Washington, DC, 1996, pp.1053.

[3] J.Meier, et al., "Microcrystalline silicon and the impact on micromorph tandem solar cells", Sol. Energy Mater. Sol. Cells, 74, 2002, pp.457.
[4] F. lannone, G. Noviello and A. Sarno. 'Monte carlo techniques to analyse the electrical mismatch losses in large-scale photovoltaic generators'. Sol. Energy. 62, 1998, pp.85-92.

[5] J. Merten, J.M. Asensi, C. Voz, A.V.Shah, R.Platz, J. Andreu, "Improved equivalent circuit and analytical model for amorphous Silicon solar cells and modules." IEEE Trans. Elect.. Dev. 45, 1998, pp. 423.

[6] Fanny Meillaud, Arvind Shah, Julien Bailat, Evelyne Vallat Sauvain, etc. "Microcrystalline silicon solar cells: theory and diagnostic tools. Photovoltaic Energy Conversion" Conference Record of the 2006 IEEE 4th World Conference 2, pp.1572-1575

[7] J. W. Bishop, "Computer simulation of the effects of electrical mismatch in photovoltaic cell interconnection circuits." Sol. Cells. 25, 1988, pp.73-89. 